\title{
The Making of Australia's Supermarket Duopoly, 1958-2000
}

\author{
David T. Merrett \\ University of Melbourne (dtm@unimelb.edu.au) \\ Level 10, The Spot 198 Berkeley Street, CARLTON VIC 3010
}

\section{Abstract:}

\begin{abstract}
Australian supermarkets had one of the highest levels of concentration among developed economies by 2000. This paper explores the making of a duopoly comprising Coles and Woolworths. We present historical data on market shares in Australia and international comparisons for around 2000. We identify the evolution of their dynamic capabilities through the lens of Teece, Pisano and Shuen's positions, paths and processes (1997). The industrial organization literature stresses interaction become rivals, notably pre-emptive strategies including sunk costs (Lee \& Ng 2007; Sutton 1991). We argue that the development of dynamic capabilities enabled the execution of various pre-emptive strategies.
\end{abstract}

JEL categories: L1, L2, L8, D43 and N7.

Keywords: Australia, supermarkets, market concentration

\section{Acknowledgements:}

This research was funded by an Australian Research Council Discovery Grant DP150100504 for 2015-18 entitled 'Regulating Australia's Retail Grocery Sector - Goals, Actors and Techniques'. I thank my colleagues Carron BeatonWells, Jo Paul-Taylor, Christopher Arup and Jane Dixon for their guidance. Thanks also to the editors, reviewers and André Sammartino.

This is the author manuscript accepted for publication and has undergone full peer review but has not been through the copyediting, typesetting, pagination and proofreading process, which may lead to differences between this version and the Version of Record. Please cite this article as doi: $10.1111 /$ aehr.12172

This article is protected by copyright. All rights reserved. 


\section{INTRODUCTION}

Grocery retailing has been transformed across the globe since the early twentieth century. Beginning in the United States of America the traditional stand-alone grocery store was challenged and replaced by self-service supermarkets owned by corporations. This model of grocery distribution spread to the United Kingdom, parts of western Europe and Australia shortly after WWII (Jeffreys 1954; Seth and Randall 1999; Hayward and White 1928; Zimmerman 1955). Moreover, penetration of mature host markets by foreign grocery retailers accelerated from the 1980s (Godley 2002; Sammartino 2007). From the 1990s supermarkets quickly emerged in developing countries in Africa, Asia and Latin America. This latter wave of the diffusion of supermarkets was linked in large part to foreign direct investment by leading supermarket chains from the developed world (Reardon, Timmer Barrett and Berdegué 2003; Traill 2006). By 2002 supermarket stores had the majority share of the retail food market in most of the world's wealthiest economies (Traill 2006, Table 1, 166).

A consequence of the rise of supermarkets as the dominate provider of foodstuffs in many countries has been a marked increase in concentration within the sector. An industry whose structure once approximated monopolistic competition became increasingly concentrated to include oligopoly and duopoly (Nordås, Grosso and Pinali 2008). There has been a growing concern about the competition and social issues that have accompanied these changes in industry structure, notably the power of supermarkets to extract rents from their suppliers, especially farmers, and the entrenchment of market power by the creation of significant barriers to entry (Dobson, Waterson and Davies 2003).

Australian experience in the evolution of a highly concentrated supermarket grocery sector was by no means unusual. However, the mix of entrants into the new sector was novel. Nearly all the supermarkets chains that came to dominance in North America and Europe by the 1980s were previously trading as grocers or were start-ups (Zimmerman 1955, chapter 2; Seth and Randall 1999; company websites for Walmart, Kroger, Costco, Albertsons, Safeway, Carrefours, Groupe Auchan, Royal Ahold, Aldi and Metro AG). In contrast, the two firms that created a duopoly in the Australian supermarket industry, Coles and Woolworths, entered from a dominant position in another form of retailing, discount variety stores. This paper is a study of how these two firms grew more quickly than their rivals to assume a position of dominance and, in contrast, what impediments faced the other firms from within the industry in meeting that competition.

Market concentration levels 
Table 1 around here

Table 1 provides data of market share in the Australian grocery industry from 1964 to 1997 . The first data point, 1964, is six years after the entry of Coles and Woolworths into the industry. Their combined share is less than 20 per cent. The other 21 groups owning multiple store, the chains, have around the same market share. The looser associations of buying groups and the stores they supply under a 'banner' hold more than a third of the market and the standalone high street shops that have not adopted the self-service model have more than a quarter. By 1978, Coles and Woolworths have nearly 40 per cent of the market, the other chains and buying group have held their share while the independents have been decimated. Nearly twenty years later, Coles and Woolworths have more than 60 per cent of the market, their growth coming at the expense of a declining share of the buying groups and the exit of the independents.

Table 2 around here

Where does Australia stand in international comparison? The figures shown in Table 2 of market share are not strictly comparable as some nations count dry goods only while others include fresh food, and some measure warehouse withdrawals and some in-store sales (Australia. Report by the Joint Senate Committee 1999, 105-21). That qualification aside, Table 2 indicates that in the 1990s Australia had one of the highest levels of market concentration in the mature grocery markets of the EU, the USA, Canada and Japan. A close comparison of distribution of firm share within the top five firms in the European Union shows that within highly concentrated markets duopolies are rare (Kuwahara 1997; Wrigley 1992; Daniel and Hernandez 2008; Cotterill 1997; Dobson, Waterson and Davies 2003, Table 1, 116 and Table 3, 116, rows 3 \& 4; Australia. Report by the Joint Senate Committee 1999, chapter 7).

\section{Data limitations}

Accounting for this divergence between Coles and Woolworths and the rest is complicated by lack of data. While there is a small body of scholarly work available (Humphrey 1998; Brown 1990, 229-56; Chow 1991; Nayga \& Riethmuller 1995; Hubbard 1996a \& 1996b; Treadgold 1996; Merrilees and Miller 2001; Gottliebsen 2003a \& 2003b), Government statistics do not permit analysis at the firm level (Round 1974). Archival material is not available for either Coles or Woolworths. ${ }^{1}$ More information is available from those public companies that were listed on the stock exchange. Unfortunately, many of the firms competing in the grocery industry were neither. While we know more about Coles and Woolworths than the rest non-archival sources such as annual reports, commissioned

\footnotetext{
${ }^{1}$ Coles' archival collection has no finding aids. See State Library of Victoria, Previous lists of Coles Myer archives MS13468/1ARCHS001.
} 
histories, and press commentary are likely to contain both omissions and possible biases. Furthermore, both companies were retailing conglomerates with a mix of food and non-food businesses whose balance altered over time. Both also operated in New Zealand on occasion. Their consolidated financial statements do not provide segment analysis before the mid-1980s and that data is of little use for our purpose thereafter (Kelly 1994; McKinnon and Dalimuntle 1993). In summary, we lack firm-specific financial data for the industry which could have been used to provide a sharper analysis of the extent of differences in performance between firms and the source of those outcomes.

In the rest of this paper we attempt to explore the factors that enabled Coles and Woolworths to create a duopoly using descriptive rather than quantitative material. In particular we draw on the dynamic capability framework developed by Teese, Pisano and Shuen (1997) to understand the origins of sustainable competitive advantage in times of rapidly changing market conditions. The behaviours of both firms examined within this framework suggests that they were able to continuously generate dynamic capabilities at a faster rate than any other rival. Competitive behaviours between firms, as discussed in the industrial organization literature, which created barriers to entry within grocery market segments by sunk costs and pre-emptive strategies also explain much of the emergence of the duopoly (Lee \& Ng; Sutton 1991). We argue that the creation of dynamic capabilities was a necessary condition for the successful exploitation of pre-emptive strategies.

\section{BECOMING A DUOPOLY}

\section{Dynamic capabilities}

Why some firms achieve a sustainable competitive advantage has been the subject of a large literature in strategic management, particularly from the resource-based view (Barney, Wright and Ketcher 2001; Prahalad and Hamel 1990; Eisenhardt and Martin 2000). However, identifying and operationalizing the full repertoire of resources, competencies and particularly capabilities, has proved to be problematic (Rouse and Daellenbach 1999; Barney, Wright and Ketcher 2001; Priem and Butler 2001; Newbert 2007). We will use the dynamic capability framework of Teece, Pisano and Shuen (1997) because it is focused towards firms coping with environments of rapid change (509). Our study starts with a major disruption in the grocery trade with the introduction of self-service, supermarket chains and shopping centres clustered around the 1950s and 1960s, and the subsequent replacement of a fragmented structure by an emerging and later a mature industry (Porter 1980, chapters 9-11). During such a transition competitive advantage was dependent upon the ability of managers 'to integrate, build and reconfigure internal and external competencies' that 'translated into new and innovate forms of competitive advantage' (516). 
The ability of a firm to navigate this uncertain environment depended not so much on a stock of resources per se but rather on behaviours borne out of practice. How well a firm can create dynamic capabilities rests on the interaction between three factors: the firm's initial position, its current endowment of assets and its routines and core competencies; the strategic paths open to it as consequence of that position; and the various processes, such as organizational functions and technical skills, which are difficult for competitors to imitate (Teece, Pisano and Shuen 1997, 518-24). We will proceed to unravel the ability of Coles and Woolworths to create dynamic capabilities under these three headings.

Given the limitations of the data discussed above we cannot observe the decision-making processes taking place within these organizations to make such changes. However, we can observe indirect proxies for competencies and capabilities: resource-bases and organization routines; learning to manage a diversified business up to 2000 which included grocery, discount variety stores, department stores, speciality stores and petrol stations; and the transfer from a U-form to a M-form organization with head office standing above the operating divisions.

Position

Our argument is that Coles and Woolworths entered the grocery business from a position of strength. The creation of organizational routines is necessarily time dependent. Coles and Woolworths had decades of experience in operating highly successful businesses in a chain of variety stores before diversifying into grocery retailing in 1958. We shall argue that the organizational routines developed by both Coles and Woolworths before they entered the grocery trade provided them with a range of powerful advantages compared to the incumbents. They already served a mass customer-base across a national market. For instance, in 1954-55, Coles ran 188 variety stores across six states, stocked with 20,000 lines and serving a million customers a day out of a population of 9.2 million (G. J. Coles and Co. Ltd, Annual Report 1954-55).

We are forced to rely on proxy measures of organizational routines. We begin by discussing those which provide the organizational environment in which capabilities were created and exploited, a stable leadership team committed to a strategic direction and an internal labour market that built a deep supply of firm-specific human capital. Both Coles and Woolworths had settled leadership teams over a long period after their establishments in 1914 and 1924, respectively. For instance, five Coles brothers, George, Arthur, Kenneth, Edgar and Norman held senior executive and board positions in the business from its inception into the 1970s. Whereas the founding five of Woolworths, H. P. Christmas, his brother-in-law C. S. Waine, S. E. Chatterton, G. W. P. Creed, and E. Williams, had a similarly long tenure from 1924 into the early 1960s, regularly serving as managing directors or chairman (Murphy 1999, 10-16, 257 and 259). Both Coles and Woolworths had quickly developed by trial and error a form of 
organization and operational practices that were appropriate to their core business of running a chain of variety stores.

In little more than a decade of operation George J. Coles, the managing director, published a description of the systems at use in his firm (Coles 1928). Decision-making was highly centralised with key strategic issues, financing store openings in good locations, and operational procedures were set by the general manager and a committee of management comprising a small number of executives, the secretary, personnel and merchandise directors and head buyers. Management within the stores was standardised, the range and pricing were also determined at the top. The number of staff within each store was determined by its size and their functions were prescribed in manuals. Systems had to be designed to record transactions, the hours worked and payments of wages, stock purchased and moved into stores, and recording stock positions and sales made, and so on. Layers of management emerged above the stores, usually on a State basis, responsible for the oversight of the operation. These coalesced around specialisation functions such as personnel, buying, advertising and the like (Coles 1928).

Developing standard hiring practices and training for additional staff were of critical importance, not least because both firms embraced an 'all promotions from within' before and for long periods after WWII. In common with other retailers both firms had used 'internal labour markets' from their beginnings hiring at entry level then sorting, selecting and training men and women for specific roles and for higher posts in the organization (Carter, M. J. and Carter, S. B. 1985; Sundstrom, W. A., 1988). As employees worked across many departments and store locations they learnt on the job, following instructions from above and developing tacit knowledge from working in teams and dealing with customers and suppliers. Most of those entering employment stayed for life, this was a 'good job', with a career ladder and benefits (Jacoby 1985). Many of them worked their way to the top, including Woolworths' Theo Kelly. Insiders at Coles such as L. R. Robinson, T. L. North, B. P. Bradbury and B E. Quinn also went on the top management and board positions from the 1950s through to the 1980s (Barber 2013; Murray 1999).

\section{Paths}

Directors and senior executives frequently visited the USA to study trends in retailing. Both firms took a close interest in two developments: the declining profitability in the discount variety store business and the rise of grocery supermarkets. Each was closely monitoring the rapid emergence of small scale supermarkets in Australia. Their vision of how the industry might develop was on a far grander scale. Sir Edgar Coles, managing director, stated in the 1959 Annual Report that 'just about every corner grocer has put in a checkout and called his shop a supermarket [but] the Company will be in the larger type of supermarket' (6). They would replicate the variety store model of operating in all states. 
Decades of prior experience in collective decision-making amongst the most senior team in these firms had built a corporate memory and a set of routines within the organizations that developed strong path dependencies, that rested on their having made 'long-term, quasi-irreversible commitments to a certain domain of competencies' (Teece, Pisano \& Shuen 1997, 515) channeling them towards related diversification (Rumelt 1986). Changes within their boards, a passing of the top positions within these groups to younger men, was critical in both taking the decision to enter the supermarket industry and to an ongoing commitment to that sector. For instance, Sir Edgar Coles, the architect of the shift into food retailing, became sole managing director in 1944 and succeeded his brother Kenneth as chairman of the board from 1963 to 1968. Theo Kelly, a champion of supermarkets, succeeded Christmas as Woolworths' managing director from 1945-71, and was also chairman of the board from 1963 until $1980 .^{2}$

\section{Processes}

At its heart the dynamic capabilities' model focuses on the ability to renew capabilities that match the shifting business environment. This requires 'appropriately adapting, integrating and reconfiguring internal and external organizational skills, resources and functional competences (Teece, Pisano \& Shuen 1997, 515). Moreover, it is essential that the resulting 'collection of routines, skills, and complementary assets ... are difficult to imitate' (Teece, Pisano \& Shuen 1997, 524). We do not have access to internal records to directly observe these changes. However, our argument is that by successfully managing an increasingly large and complex businesses, the scope of which is shown in Table 3, Coles and Woolworths must have generated and exploited dynamic capabilities, particularly in operating systems, relations with suppliers, decision-rules with respect to stocking and pricing and so on, which would have been difficult for rivals to imitate. We can demonstrate that they changed the composition of their human capital and were able to augment it by learning from other firms. Moreover, operating an increasingly diversified retail organization necessitated a recasting of the organization structure from one which had been highly centralised to a M-form structure tied to market segments. Coles and Woolworths both managed this structural transition.

\section{Table 3 around here}

Their success in the rapidly expanding grocery market posed great challenges to both firms. The increasing number of grocery stores that quickly spread across the continent with a growing range of stocked goods, together with entry into other retail markets, placed burdens on both organizations to find staff with the requisite skills. Both Coles and Woolworths had prior experience in the food industry from their operating large cafeterias alongside the

\footnotetext{
${ }^{2}$ Family ties were important in both organisations. Kelly was son-in-law of one of the founding five, Ernie Williams. Murray 1999 , 121.
} 
variety stores which also stocked some food items (Barber 2013; Murray 1999). However, entering the supermarket business posed considerable challenges:

The main challenge in selling food was its perishable nature, which required a high turnover. A new ordering and warehousing system had to be established, as did new systems of display, pricing, packaging and accounting. It was not simply a matter of establishing efficient systems, there was a whole new opposition to meet and new suppliers with whom to establish relationships (Barber 2013, 50).

Acquisition of firms already operating in the grocery trade was the first path taken to accumulate knowledge. Coles relied heavily on the management of S E Dickens and Wilkinson \& Co to guide their entry into food retailing and to train staff, as did Woolworths with BCC (Barber 2013, 63; Murray 1999, 104).

The later move into American style discount department stores required direct injections of know-how from foreign companies (Bailey 2017). Fearing that a foreign retailer might enter the Australian market to exploit this underdeveloped market, Woolworths, Coles and the Department store Myer all entered the segment with their offerings, BIG W [1964], Kmart [1968] and Target [1985], respectively (Barber, 66; Murray 1999, 135). Coles had gained an immediate advantage by using the input of the American retailer, S. S. Kresge, in establishing and operating its successful Kmart chain as joint venture. As Bailey $(2017,5-6)$ notes:

For Coles, the partnership made available experience and expertise that S. S. Kresge had acquired through 5 years of DDS operations in the American market. Management structures, store layouts, fixtures, branding, colouration, and signage were all copied across. Where advantageous, stock was purchased through the American company's buying networks, providing benefits of scale unavailable to Australian companies.

Despite the apparent advantages to Coles from this arrangement it terminated the arrangement in 1978, suggesting that the beneficial effects of the transfer had faded (G. J. Coles Limited, Annual Report 1979, 2 \& 8). In contrast, Woolworth did not have the advantage of any transfer of knowledge to aid its management of Big W. The business struggled on with limited success against Kmart until the mid-1980s. The turnaround was sparked by a strong personal connection with Wal-Mart that resulted in the transfer of much of that firm's operating systems. Applying this new knowledge radically improved Woolworths' performance in both its general merchandise and later the grocery business (Bailey 2107, 13-18). The struggles of Coles to successfully transfer the knowledge created by S. S. Kresge in the USA into its Kmart operations suggests that it and Woolworths had different 'absorptive capacity' to learn from external sources (Lane and Lubatkin 1998 463-6; Qian and Acs 2013).

The growth of the supermarket business and diversification forced both Coles and Woolworths to change their human resource management practices as the capacity of the internal labour market to deliver appropriately 
trained staff weakened over time. Gradually the old order gave way as senior executive roles and specialist roles were filled from outside the organizations. For instance, Coles-Myer chose Peter Bartels, ex-MD of the brewery CUB as CEO from [1992-96] and he was followed by Dennis Eck [1997-2001] a supermarket executive from the USA (Coles-Myer Annual Reports). Moreover, both Coles and Woolworths came to offer financial incentives to directors and senior executives for retention and to meet performance hurdles. Coles lead the way from the early 1980s (G. J. Coles 1983, Chairman's Report; Coles Myer 1995 Annual Report; Woolworths 2002 Financial Report, 37). By 2000 performance incentive bonuses and vested share options made up roughly a third of the remuneration of Woolworths' top executives (Woolworths 2000, Concise Report, 35).

The composition of the board of directors also shifted over time towards a greater professionalisation and collectively the boards came to have a business and social reach that extended far beyond these organizations. As noted above the boards of both Coles and Woolworths had been heavily weighted by their founders and family members until the 1970s. Thereafter, partly in response to government mandated changes in corporate governance (Cheffins 2002), there was a separation of the roles of chairman and managing director. By 2000, non-executive directors were in the majority and nearly all also sat on the boards of other companies. They were better educated than their predecessors as most had University degrees and three were women (Coles-Myer 2000, Annual Report, 20; Woolworths 2000, Annual Report, 28-9).

\section{Organizational design transition from U-form to M-form}

By entering the grocery trade both Coles and Woolworths had shifted from operating in a single market, discounting general 'variety' merchandise, to becoming a diversified organization operating in two related businesses. Many challenges were faced in successfully running the combined businesses as '...difficulties in merging the cultures, processes and sales techniques of the variety and grocery stores remained a constant thorn in the company's side' (Barber 2013, 64). Directors and senior management had to find ways to rationally allocate capital between the competing claims of the grocers and the general retailers. Overtime both companies learnt what functions could be best handled centrally and what needed to be run within each division. Each division served a distinct set of customers, a unique set of operational issues and funding requirements. Working out appropriate market positioning took time as stores were rebranded and formats altered. The different types of Coles' discount department stores, Kmart and post-merger with Myer Target, cannibalised one another's customer base. Coles struggled to compete at the lower end of the grocery market in the 1990s enabling Aldi to enter the segment (Gorecki 2016). 
The management literature suggests that a firm with a diversified business that can successfully transition to a M-form division structure will outperform a rival with a similarly diversified operation that retains a U-form organizational structure (Chandler 1962; Ezzamel and Watson 1993; Hoskisson 1987). However, this generalization is qualified by several studies. First, with respect to differences between national business systems as Cable and Dirrheimer (1983) do not confirm the result for German firms. Second, that a protracted transition is less effective that a swift process (Hoskisson and Galbraith 1985). Third, that the new M-form organizational design may not function as it should in resolving the underlying tensions within the diversified firm if insufficient attention has been paid to the role of 'internal decision-making and control apparatus' (Williamson and Bhargava 1972, 127).

We can construct a time-frame of a shift from a U-form to a form of M-form from the annual reports and histories of both Coles and Woolworths. The organizational responses by Coles and Woolworths as they grappled with the need to re-design the architecture of business is best shown in the changing titles and responsibilities of the directors and top managers. Taking Coles as an example we see a dramatic shift between 1964 and 1974 (G. J. Coles, Annual Reports 1964 \& 1974). In 1964 the administrative structure still bore the weight of the past. Senior men filled the head office or 'staff' roles: finance, secretary, real estate, personnel, building and equipment, accounting and systems, accounting and PR. However, the roles attached to running the business or 'line' managers are still weighted towards the variety stores with buyers for variety, drapery, hardware, and cafeterias. There was only a single position for a supermarket director. This continued Coles' federal form of organization with its head office supported by managers in each state. These managers now had oversight of both the grocery and variety businesses, a blurring of responsibilities.

By 1974 the imperatives of diversification meant that there were additional head office functions: which now included planning, development finance, distribution centres, and supervision and store operations. There was also a formal recognition of the new divisions and one presumes the responsibilities sheeted home to those in charge: Supermarket and grocery, Food service, Kmart and Variety divisions. Buyers are still separated by function much as before, variety, drapery and hardware. However, the state managers have been joined by general managers for supermarkets and groceries in all mainland states except Victoria. Coles' administrative structure clearly was shifting towards a version of a M-form.

By 1990 Coles-Myer had the form if not the substance of a M-form organization. The various divisions, each a profit centre, the Department Stores, Food and Liquor, Other Food and Liquor, K Mart and Specialty Stores, and Target, reported to the chief executive. These operating divisions were supported by the Executive Office, Corporate Affairs, Finance \& Administration, Personnel, and Planning \& Development (Coles-Myer 2000, Annual Report, 34-35). 
Woolworths travelled down a similar path of organizational design as it accommodated itself to the emergence of a large supermarket business and additional retailing chains. Through the 1960s and 1970s the organizational structure was re-arranged by adding new functions onto to old U-form design before separating out each business segment as a Division within its own chain of command under its director in the 1980s (Murray 1999 $137 \& 197)$. However, it took the best part of ten years for the roles of head office and the Divisions approximated to those shown on the organization chart (Murray 1999, 175-6, 215 \& 219; Treadgold 1996, 6).

These narratives make it clear that might the transition from a U-form to a M-form organizational design came slowly and at times may have been sup-optimal. In both companies the change was incremental rather than quantum so reducing its effectiveness (Hoskisson and Galbraith 1985). Woolworths' experiences suggest that there was a serious misalignment within its 'internal decision-making and control apparatus' relation to the respective roles of the board and head office and the operating divisions (Williamson and Bhargava 1982). However, their collective failures in this matter helps us understand the evolution of a duopoly. Both Coles and Woolworths muddled through in finding an organizational form for an increasingly diversified retail firm. If one had failed to manage that transition over much the same timeframe then their more successful rival would likely have emerged as the dominant firm.

\section{BARRIERS TO ENTRY AND PRE-EMPTIVE STRATEGIES}

The high levels of concentration in mature supermarket industries across the world suggest that the industry has significant barriers to entry. However, the configuration of firms' market share between countries differed significantly (Dobson, Waterson and Davies 2003). The evolution of market share amongst incumbents was

influenced by two factors: the available economies of scale; and the range and strength of pre-emptive strategies used by first-movers (Lee \& Ng 2007). It is likely that barriers to entry into the Australian market for groceries increased substantially from 1958 to 2000 for a variety of reasons. There were economies of scale with respect to raising funds, managing a larger stable of stores, and ancillary assets such as distribution centres and logistic services, advertising and using monopsony power to bargain with suppliers. Moreover, first-mover firms into groceries were able to block the expansion of rivals by employing pre-emptive strategies such as exploiting national brand recognition. shifting into market niches that were difficult for rivals to follow, and to capture superior sites.

While neither Coles or Woolworths were 'first-movers' into the supermarket business they were pioneers and because of the resources and skills they had developed in the variety store business enjoyed several powerful advantages. We will argue that Coles and Woolworths' access to capital was a critical source of sustainable advantage in increasing market share. They were able to raise funds at lower cost than their smaller rivals and have greater leverage in their balance sheets. These funds enabled them to build their store numbers more rapidly and in 
gaining access to the best sites creating barriers to entry in local markets, and to spend more heavily on advertising. Their greater funding contributed to the development of economies of scale and scope across the corporations' business portfolios.

Table 4 around here

As shown in Table 4 Coles' and Woolworths' issued capital was far greater than that of their rivals. Their combined share was 85 per cent in 1958 which rose to 90 per cent in 1964, 97 per cent in 1984 before falling back to 92 per cent in 2000 after two of the larger wholesale groups, Foodland Australia Ltd and Davids had listed on the stock exchange in 1990 and 1994, respectively. Not all of Coles' and Woolworths' equity served the supermarket business but we can get a rough measure of its allocation by comparing the number of stores and revenues from the food and liquor division compared to the rest. ${ }^{3}$ Coles-Myer's Annual Review for 1999 shows that its Food and Liquor division operated 60 per cent of the more than 2000 stores and generated 58 per cent of total sales. At the margin both those firms could inject more capital into their supermarket business than any of the incumbents in the industry in 1958 or by subsequent entrants.

The scale of Coles and Woolworths' capital position provided additional advantages because of their bluechip status they could raise fresh equity more often and cheaply. Both accessed the Euro-bond markets from the 1970s and growth of a corporate debt market in Australia in the 1980s provided other sources of finance that were out of reach to smaller firms (Hirst 1974, 469-70; Davis 1993, 74). Coles and Woolworths had been able to leverage their balance sheets using more debt relative to equity, thus raising their rate of return on shareholder funds. For instance, Coles' issued capital had declined as a proportion of their total assets from 42 per cent in 1959 to eight per cent by 1984 , by which time debt was greater than paid capital (G. J. Coles, Annual Reports 1959 \& 1984).

Regulations restricting the inflow of foreign capital hindered the performance of foreign entrants in the supermarket industry, Safeway (Australia) [1963-1986] and Dairy Farm International, owners of Franklins [19762001]. Australian governments became increasingly concerned about foreign takeovers in the 1960 s. This led to a range of policies including exchange controls until 1984 to curb the inflow of funds for certain purposes, placing higher costs on foreign firms' borrowing in local markets in the late 1960s and early 1970s, oversight of take-overs by foreign firms from the early 1970s and moves towards forcing foreign companies to issue equity to Australian nationals (Safarin 1985, Table 3, 8-9). Furthermore, actions by the US government to defend the dollar in the 1960s also curtailed Safeway Inc's ability to export capital abroad, and it ended capital transfers to its Australian subsidiary in 1967 (Pratt 2006, 159; Schedvin 1992, 371-74).

\footnotetext{
${ }^{3}$ Their accounts do not show the allocation of funds between business segments.
} 
Coles and Woolworths' expanding capital resources enabled them to make strategic investments that blocked and pre-empted their rivals (Sutton 1991; Lee \& Ng 2007). For instance, between 1956 and 1960 Coles acquired four firms in food retailing, Penneys, S E Dickens, Wilkinson \& Co (Beilby) and Matthews Thompson, which had a total of 366 stores (Barber 2013, 43 \& 53-55). Woolworths, on the other hand, acquired more chains up to the late 1960s: Brisbane Cash and Carry (BCC), John Wills Holdings P/I, Food Fair, Flemings, Centralian Traders, Nancarrows and Crofts Stores, but fewer stores, 279 (Murray 1999, 104-106, 113-114, 119-21 \& 147).

By 1964 Coles and Woolworths were operating 751, or 41 per cent, of all grocery chain stores (Briggs and Smyth 1967, Table 1 (8), 16). While both Coles and Woolworths closed many of these stores because they were too small or poorly sited, the bulk of their market presence in the mid-1960s rested on the acquisition of 645 stores in the previous years. Both firms were able to fund these acquisitions in whole or part by the issue of new stock to the acquired firms (Jobson's 1969, 120 \& 531-2). The only exception was Coles’ payment of $£ 1.025$ million in cash as part of its $£ 4.175$ million acquisition of Penny’s stores in Queensland (Argus 26 July 1956).

Having removed many of their most able competitors at that point in time and having gained footholds in multiple states the two major chains continued to increase the number of stores predominantly through greenfield investments. Later acquisitions while sizeable, for instance, Woolworths' gained 120 stores from its acquisition of Safeway (Australia) in 1985 and in 1987 Coles-Myer acquired Bi-Lo and later Shoeys' gaining an additional 20 and 34 stores, were of less strategic importance (Barber 2013, 93). These transactions were funded by the issue of new shares (Jobson's 1986/1987, 306 \& 568).

Australian anti-trust legislation did not have any provisions restricting take-overs that limited competition until the Trade Practices Act 1974. This allowed Coles and Woolworths to freely acquire those chains in the 1950s and 1960s that significantly increased their market share. The s.60 test in the 1974 Act as to whether an application for a merger could be refused was that it would result in 'lessening of competition.' However, this test was significantly weakened in 1978 with the introduction of a test of the take-over now being one that would result in market 'dominance'. After further investigation by the Cooney Committee in 1991 the test reverted to a 'lessening of competition' (Fryer 2006, 348, 363-4 and 369). However, the new stance of the competition regulator in the 1990s was more of a deterrent to the smaller supermarkets and wholesalers that found it difficult to make quantum jumps in market share through take-overs. For instance, the consolidation of the wholesale grocery segment in the mid1990s was delayed several times by the interventions of the Trade Practices Commission. These included delays in sanctioning a proposed merger of the four leading wholesale grocers in 1993, and the Trade Practice Commission's ruling in the battle between QIW and Davids to acquire Composite (Canberra Times. 21 December 1993; and 12 August 1995; Australian Competition and Consumer Commission 1996). 
After the early takeover rush Coles and Woolworths continued to expand their store openings in cities and towns faster than their rivals. In doing they achieved a 'distribution advantage by covering every available 'space' or market opportunity' (Lee \& Ng 2007, 334). Site selection was an important element of the expansion of the network as securing a location enabled the creation of a spatial monopoly as the first arrival deterred followers into that catchment area. An empirical test of the effect of proximity to a rival supermarket site produced a statistically significant result that a store without a close by rival had higher prices for the same basket of goods. Intrusion was met with price 'war' (Australian Competition and Consumer Commission, 2008, 180-95 and 467-73; Australia. Report by the Joint Senate Committee 1999, 74-77).

Coles and Woolworths enjoyed an additional locational advantage in site selection as shopping centre developers and landlords gave them preferential treatment in lease agreements compared to other tenants and often excluded supermarket rivals. In 2000 there were 918 shopping centres in operation of whom 629 were based around a major supermarket store, and supermarkets had a significant presence in the remainder (Jebb Holland and Dimasi 2001, Tables 1.1, 1.2 and 1.3, 4, 6 \& 8). Existing land zoning and planning laws also favoured the two largest firms (Arup, Beaton-Wells and Paul-Young 2018).

Over time, Coles and Woolworths were best placed to introduce new modes of supermarkets, with greater floor space and more stocked items. For instance, the floor space in Coles' stores rose from between 2,000-2,400 square metres in the late 1960 s to between 3,800 to 5,000 square metres the late 1980 s. Over the same period, the number of products on offer rose from 4,500-8,000 in 1969/70 to between 15,000 and more than 40,000 in the 1990s (Jones 1999, 37-39). They were able to fund the introduction of new technologies in-store and upstream into their distribution and logistics functions. By doing so, Coles and Woolworths pushed up the sunk costs required of rivals to follow them.

Supermarkets relied heavily on advertising which Sutton (1991) identifies as an important element of endogenous sunk costs which enhance consumers' willingness to pay for a firm specific product raising entry barriers. It was a cost that rivals needed to match (Chapter 3). Coles and Woolworths entered the trade with a powerful advantage over their rivals because of brand recognition. Both relied heavily on mass advertising through multiple communication channels. Their rivals, with two exceptions, had chains in only one state. The costs of establishing a comparable brand recognition beyond their home-base would drive up advertising costs. Coles and Woolworths financial resources enabled them to continue undertaking sustained marketing campaigns, including the extensive use of television as a communication medium (Murray 1999; Barber 2013, 59).

Moreover, their significant financial resources enabled these two firms to take new strategic options more easily than their rivals. As discussed above, Coles and Woolworths were diversified retailers, beginning with variety stores and supermarkets and later including discount department stores, K-Mart, Big W and Target, department 
stores, and a range of specialty stores (Murray 1999; Barber 2013). None of their rivals in the supermarket industries undertook such horizontal diversification, although some engaged in vertical diversification being a wholesaler and retailer. Coles and Woolworths expanded their range of economies of scope. Having a large war chest, these two market leaders were better placed than their rivals to seize the new opportunities arising in the sector from events such as Safeway Inc's exit from Australia in 1985 that resulted in Woolworth's acquisition of many new stores, the deregulation of shopping hours in the early 1990s and of liquor licensing, and to enter petrol retailing (Murray 1999, chapters 17-20; Barber 2013, chapters 8 \& 9).

\section{CONCLUSION}

The central question raised in this paper is why was the Australian supermarket industry a duopoly by the late twentieth century? We argue that the simultaneous entry of two successful non-grocery firms operating in the majority of states and with strong brand recognition in the early years of the emerging supermarket industry holds the key. Coles and Woolworths possessed vastly superior resources, competencies and capabilities than any of their rivals in the late 1950s. The margin between the two largest and the rest was most likely grew over time.

Both firms had an administrative heritage that provided a strong foundation for their successful entry into the grocery trade. They were experienced retailers led by a stable leadership group, with a highly effective centralised organizational structure which could manage across distance. We argued above that the organizational structures of both firms successfully adapted to becoming a relatedly diversified firm. New skills and knowledge were discovered and incorporated into strategic decision-making and operating systems. Both successfully navigated the transition from a U-form to a M-form structure.

Coles and Woolworths entered the grocery business with financial resources that dwarfed their smaller rivals. Having access to cheaper funding through equity and debt these two firms gained a significant advantage in increasing their market share. They had the ability to buy up rivals, to invest in greenfield stores and distribution centres, and enjoyed privileged access as anchor tenants in shopping centres. They led the race to capture catchment areas for grocery distribution servicing a growing and car driving population. Their command of superior site locations combined with a national brand and mass advertising blocked their smaller and later arriving rivals. Coles and Woolworths' high market share enable them to leverage their monopolistic power dealing with suppliers. They enjoyed the enviable choice of higher margins, which could sustain the branch expansion and replenishment, or the ability to compete on price if needs be.

Was the rise of a duopoly inevitable? Not necessarily. However, the importance of economies of scale in purchasing, selling and advertising and the associated barriers to entry make it likely that the mature industry would 
be concentrated. How did Coles and Woolworths manage to increase their market share at roughly the same pace over four decades? Our discussion of the three steps spelt out in Teece, Pisano and Shuen (1997) suggest that the firms shared a very similar 'position' when they entered the grocery business and that each introduced broadly similar 'processes' to create and exploit new dynamic capabilities. The path dependency forged by their initial 'position' directed both in the same direction when a new market segment, and thus strategic 'path', opened in Australia, supermarkets. Their access to greater and cheaper financial capital was another important source of advantage that could be leveraged to create barriers to entry, impose sunk costs on rivals and pre-empting other firms from acquiring the best store sites.

Why could none of the rival firms grow their market share over the long haul? All the domestic firms entered the supermarket industry from a far weaker 'position'. None of them possessed a bundle of resources or organizational routines that matched the competences of Coles and Woolworths as retailers to a national market. None began with an administrative structure that had was operated by a managerial hierarchy. For instance, two of the most successful discount grocers, Franklins in Sydney and Tom the Cheap in Western Australia, operated with a skeletal head office. Both were eventually acquired when Franklins' two ageing principals retired and when Wardle's private company which owned Tom the Cheap went bankrupt in 1979 and 1977, respectively (Sydney Morning Herald 22 July 1978; Briggs \& Smyth 1967, 141; Stannage 1979). The various state-based wholesalers supplying the independents lacked scale (Pertzel 2005 209-25) and their attempts to consolidate via mergers were compromised by regulatory action. The two foreign entrants, Safeway Inc and New Dairy Farm International, did not present a sustained challenge. ${ }^{4}$ Regulatory restriction on capital movements out of the USA and into Australia may have cut one avenue of advantage for Safeway (Australia). The transfer of knowledge from the parent may have not been converted into effective 'processes'. Moreover, troubles facing Safeway Inc in the US market in the mid-1980s led to its being acquired and its Australian operations being sold.

The Australian experience of a concentrated supermarket segment is not unusual. Furthermore, our explanation of the increasing market share of leading firms, a mix of the creation and exploitation of dynamic capabilities, and the ability of create barriers to entry, impose sunk costs and execute pre-emptive strategies, likely fits the experience of other mature markets. However, each national story has its own distinct character. For instance, in Australia the rise in market concentration was not checked by anti-trust legislation. International entrants were scarce and unsuccessful. The two firms comprising the duopoly had their origins outside of the grocery industry, and the eventual level of concentration was unusually high. A lack of firm-specific financial data

\footnotetext{
${ }^{4}$ The third foreign firm entered the market but too late to make a difference before 2000. In 1998 the South African Metoz, formerly Metro Cash and Carry, acquired Davids which had previously absorbed QIW in 1996 (Grant Samuel 2004, 38).
} 
and access to internal documents has shaped our choice of analysis. We opted for a descriptive approach, interrogating the dynamic capabilities framework using proxy measures to shed new light on the significance of the paths taken over several decades to reach these outcomes. In the process we demonstrate the value of a long term perspective in understanding contemporary policy issues.

Table 1: Estimates of national grocery market shares in Australia, 1964 to 1997

\begin{tabular}{|l|c|c|c|c|}
\hline & 1964 & 1978 & 1997 & $\begin{array}{c}\text { Percentage } \\
\text { point change } \\
1964-97\end{array}$ \\
\hline Coles-Woolworths & 18.1 & 37.3 & 61.6 & 43.5 \\
\hline Other Chains & 16.9 & 16.1 & 15.0 & -1.9 \\
\hline Buying Groups & 37.2 & 34.9 & 23.4 & -13.8 \\
\hline Independent & 27.7 & 11.7 & 0.0 & -27.7 \\
\hline Total & 100.0 & 100.0 & 100.0 & \\
\hline
\end{tabular}

Note: The data is not strictly comparable across the dates. The numbers should be taken as indicative of trends.

Sources: 1964 data adapted from Briggs and Smyth (1967), Table 1 (8), 16. The sales figure for groceries for 1963-64 from Year Book Australia, 1966, 1151. 1978 data from Retail World 1978 Annual Report reproduced in Report by Prices Justification Tribunal (1979), table 5.3, 117. 1997 data from Retail World (1998), 5. 
Table 2: Concentration ratios in international grocery sector 1990s (per cent)

\begin{tabular}{|l|l|}
\hline Australia top 21998 & 64 \\
\hline Australia top 31998 & 75 \\
\hline Britain top 5 1990 & 61 \\
\hline Canada top 4 2004 & 59 \\
\hline EU 15 countries top 5 weighted average 1999 & 49 \\
\hline United States of America top 5 1985 & 23 \\
\hline
\end{tabular}

Sources: Rows 1 and 2, Report by the Joint Senate Committee on the Retailing Sector (1999), Table 4.3, 43; Row 3, Wrigley (1992), Table 2, 729; Row 4 Daniel and Hernandez (2008) Table 4, 13, s 1 and 2, Row 5, Dobson, Waterson and Davies (2003) Table 1, 113 and Table 3, 116; Row 6, Wrigley (1992), Table 4, 729.

This article is protected by copyright. All rights reserved. 
Table 3: Coles, store numbers and categories, 1964-2000

\begin{tabular}{|l|c|c|c|c|}
\hline $\begin{array}{l}\text { Food \& } \\
\text { Liquor }\end{array}$ & 293 & 359 & $1990^{*}$ & $2000^{*}$ \\
\hline $\begin{array}{l}\text { General } \\
\text { Merchandise }\end{array}$ & 259 & 232 & 138 & 1260 \\
\hline $\begin{array}{l}\text { Department } \\
\text { Stores }\end{array}$ & & & 79 & 68 \\
\hline $\begin{array}{l}\text { Apparel \& } \\
\text { Home }\end{array}$ & 552 & 591 & 1586 & 2676 \\
\hline Total & & & 2082 \\
\hline
\end{tabular}

Notes: *Coles-Myer. \# first year in which Coles presented store numbers. We have allocated them to the 2000 category classifications.

Food \& Liquor: 1964 - New World Supermarkets (29), Food Markets (264) 1970 - New World Supermarkets (120), Food Markets (167) and K mart Food (5). 1980 - New World Supermarkets (320), Foodmarkets (39) 1990 - Coles New World (386), Bi-Lo (116), Liquorland (283) and Red Rooster (133). 2000 - Coles (427), Bi-Lo (163), Liquorland (430), Red Rooster (240).

General Merchandise: 1964 - Variety stores (248) and Country Department Stores (11). 1970 - Variety stores (256) \& Country Department Stores. 1980 - Variety stores (159), Kmart (56), Kift shoe stores (16) and Auto (1) 1990 - Kmart (138). 2000 -Kmart (164), Kmart Tyre \& Auto (50), Officeworks (47) \& World 4 Kids (6).

Department stores - 1990 Myer and Grace Brothers stores (79). 2000 - Myer and Grace Brothers Stores (68).

Apparel \& Home: 1990 Target (79), Fossey (203) \& Katies (170). 2000 - Target (133), Fossey (132) \& Katies (211).

This article is protected by copyright. All rights reserved. 
Table 4: Capital resources of Australian listed supermarket operators, 1958-2000 (\$ms)

\begin{tabular}{|c|c|c|c|c|}
\hline & 1958 & 1968 & 1984 & 2000 \\
\hline G J Coles< & 25.0 & 59.6 & $124.2^{\wedge}$ & $1,213.8$ \\
\hline Woolworths & 23.4 & 48.6 & 123.0 & $1,077.0$ \\
\hline Moran \& Cato & 2.0 & $5.8 \#$ & - & - \\
\hline Permewan Wright & 2.0 & 5.0@ & - & - \\
\hline Western Stores & 2.8 & - & - & - \\
\hline Australian Safeway & - & 2.8 & 4.8 & \\
\hline $\begin{array}{l}\text { Crooks National } \\
\text { (Holdings) }\end{array}$ & 1.2 & $1.5 \$$ & - & - \\
\hline Barry \& Roberts & 0.4 & 1.7 & $1.7+$ & - \\
\hline $\begin{array}{l}\text { Associated Co-op } \\
\text { Wholesalers* }\end{array}$ & - & 1.0 & - & - \\
\hline $\begin{array}{l}\text { Interstate } \\
\text { Buyers/Foodland } \\
\text { Holdings* }\end{array}$ & 0.2 & 0.7 & - & - \\
\hline Wholesalers* & 0.2 & 0.4 & - & - \\
\hline Davids* & - & - & - & 127.0 \\
\hline $\begin{array}{l}\text { Foodland Associated } \\
\text { Limited (FAL)* }\end{array}$ & - & - & - & 78.5 \\
\hline Total & 57.2 & 120.4 & 253.7 & $2,496.3$ \\
\hline
\end{tabular}

Notes: Paid capital only measure available for all companies shown. *Signifies buying groups, some of whom were vertically integrated running their own stores plus supplying 'independents'. < Coles-Myer in 2000; ^Coles accounts ex-K mart (Australia), whose issued capital was $\$ 16.0 \mathrm{~m}$, \# taken over by Permewan Wright in 1969; @ acquired by private company in 1976; + acquired 1985 by private company, $\$$ taken over in 1971 by private company, Davids listed 1994, capital 1998, FAL listed 1990, capital 1998.

Source: Jobson's Investment Digest and Jobson's Year Book of Public Companies 1959, 1969, 1984 and 2000.

This article is protected by copyright. All rights reserved. 


\section{References}

Argus. Coles-Pennys deal worth £4,175,00. 26 July 1956.

Arup, C., Beaton-Wells, C. and Paul-Taylor, J. (2017), Regulating supermarkets: The competition for space. UNSW Law Journal, 40, 3, 1035-71.

Australia. Prices Justification Tribunal (1979) Processed Food Industry: An Examination of the Prices and Margins Applying to the Manufacture (Melbourne: Commonwealth Government Printing Unit).

Australia. Report by the Joint Senate Committee on the Retailing Sector (1999), Fair Market or Market Failure? A Review of Australia's Retailing Sector (Canberra: Parliament of the Commonwealth of Australia).

Australia. Year Book Australia No. 52 (1966) (Canberra).

Australian Competition and Consumer Commission (1996) ACCC authorises Davids/QIW merger. https://www.accc.gov.au/media-release/accc-authorises-davids/qiw-merger. Accessed 29 June 2017.

Australian Competition and Consumer Commission (2002) Report to the Senate by the ACCC on prices paid to suppliers by retailers in the grocery industry.

Australian Competition and Consumer Commission (2008) Report of the ACCC inquiry into the Competitiveness of Retail Prices for Standard Groceries.

Bailey, M. (2017) Absorptive capacity, international business knowledge transfer, and local adaptation: establishing discount department stores in Australia. Australian Economic History Review, 57: 194-216.

Bain, S. J., (1956) Barriers to New Competition: Their Character and Consequences in Manufacturing Industries (Cambridge MA: Harvard University Press).

Barney, J. M., Wright D. and Ketcher, J. Jnr. (2001) The resource-based view of the firm: Ten years after 1991. Journal of Management, 27: 625-41.

Barber, S. M. (2013) Coles 100 Years of Quality, Service and Value (Thornbury, Vic: Bounce Books).

Beaton-Wells, C. and J. Paul-Taylor (2017) Codifying Supermarket-Supply Relations: A Report on Australia's Food and Grocery Code of Conduct. Supermarket Power Project, Melbourne Law School.

Briggs, D. H. and Smyth, R. L. (1967) Distribution of Groceries: Economic Aspects of the Distribution of Groceries with Special reference to Western Australia (Perth: University of Western Australia Press).

Brown, L. (1990) Competitive Marketing Strategy: Developing, Maintaining and Defending Competitive Position (Melbourne: Thomas Nelson).

Canberra Times. Davids quits merger plan Trade Commission blamed. 21 December 1993.

Canberra Times. Composite withdrawal dashes \$2b empire. 12 August 1995.

This article is protected by copyright. All rights reserved. 
Cable, J. and Dirrheimer, M. J. (1983) Hierarchies and markets: An empirical test of the multidivisional hypothesis in West Germany. International Journal of Industrial Organization, 1: 53-62.

Carter, M. J. and Carter, S. B. (1985) Internal labour markets in retailing: The early years. Industrial and Labor Relations Review, 38, 4: 586-98.

Chandler, A. D. Jr. (1962), Strategy and Structure: Chapters in the History of American Industrial Enterprise (Cambridge, MA: MIT Press).

Cheffins, B. R. (2002), Comparative corporate governance and the Australian experience. In I. Ramsay, ed. Key Developments in Corporate Law and Trusts: Essays in Honour of Professor Harold Ford (Sydney: LexisNexis Butterworths), pp. 13-38.

Chow, W. (1991) The supermarket retailing industry. In G. Lewis, A. Morkel and G. Hubbard, eds. Cases in Australian Strategic Management (New York: Prentice Hall), pp. 100-23.

Coles, G. J. (1928) Chain Store Economics and Organisation (Melbourne: Macmillan \& Co. Ltd. In association with the Melbourne University Press).

Coles, G. J., Annual Report, various.

Coles-Myer. Annual Review, various.

Cotterill, R. W. (1997) The food distribution system of the future: Convergence towards the US or UK model? Agribusiness, 13, 2: 123-35.

Daniel, C. and Hernandez, T. (2008) The impact of corporate concentration on the Canadian retail economy. Geography Research Forum, 28: 8-20.

Davis, K. T., (1993) Corporate debt markets, In M. K. Lewis and R. M. Wallace, eds. The Australian Financial System, (South Melbourne: Longman Cheshire), pp.249-81.

Dobson, P. W., Waterson, M., and Davies, S. W. (2003) The patterns and implications of increasing concentration in European food retailing. Journal of Agricultural Economics, 54, 1: 111-125.

Eisenhardt, K. M. and Martin, J. A. (2000) Dynamic capabilities: what are they? Strategic Management Journal, 21, 10/11: 1105-1121.

Ezzamel, M. and Watson, R. (1993) Organizational form, ownership structure and corporate performance: A contextual empirical analysis of UK companies, British Journal of Management. 4: 161-176.

Fisher, L. M. (1988) Safeway Buyout: A Success Story. The New York Times. http://www.nytimes.com/1988/10/21/business/safeway-buyout-a-sucess-story.html? retrieved 28/06/2017.

Fryer, T. A. (2006) Antitrust and global capitalism, 1930-2004 (Cambridge: Cambridge University Press). 
Godley, A. (2002) What was new in the 1980s?, International Review of Retailing, Distribution and Consumer Research, 12, 1: 29-37

Gorecki, A. (2016) Coles Relaunching BI-LO?, Retail Directions, 27 September http://retaildirections.com/blog/colesrelaunching-bi-lo/. Accessed 10 July 2017.

Gottliebsen, R. (2003a) Woolworths' project refresh, 10 Best and Worst Decisions of Australian CEOs (Ringwood Vic.: Viking), pp. 16-29.

Gottliebsen, R. (2003b) Coles Myer's department store disaster, 10 Best and Worst Decisions of Australian CEOs (Ringwood Vic.: Viking), pp. 212-25.

Grant Samuel (2005), Acquisition of Foodland by Woolworths and Metcash, Independent Expert's Report, Foodland Associated Limited Scheme Booklet (Foodland Associated Limited), p. 38.

Hayward, W. S. and White, P. (1928) Chain Stores: Their Management and Operations (New York: McGraw-Hill Book Company).

Hirst, R. R. (1974) Finance for economic development. In R. R. Hirst. and R. H. Wallace, eds. The Australian Capital Market (Melbourne: Cheshire), pp. 469-70.

Hoskisson, R. E. (1987) Multidivisional structure and performance: The contingency of diversified strategy, Academy of Management Journal. 30, 4: 625-644.

Hoskisson, R. E. and Galbraith, C. S. (1985) The effect of quantum versus incremental M-form reorganization on performance: A time-series exploration of intervention dynamics. Journal of Management, 11, 3: 55-70.

Hubbard, G. (1996a) The supermarket retailing industry in 1994. In Lewis, G., et.al. eds. Cases in Strategic Management: Australia and New Zealand, second edition (Sydney: Prentice Hall), pp.1-18.

Hubbard, G. (1996b) Coles Myer Ltd. In Lewis, G., et.al. eds. Cases in Strategic Management: Australia and New Zealand, second edition (Sydney: Prentice Hall), pp.160-74.

Humphrey, K. (1998) Shelf Life: Supermarkets and the Changing Cultures of Consumption (Cambridge: Cambridge University Press).

Jacoby, A. A. (1985) Employing Bureaucracy: Managers, Unions, and the Transformation of Work in American Industry, 1900-1945 (New York: Columbia University Press).

Jebb Holland and Dimasi (2001), Shopping Centres in Australia, Vital Statistics, April 2001, www.scca.org.au/wpcontent/uploads/2015/06/Vital-Statistics-April01.pdf. Accessed 11 July 2017.

Jefferys, J. B. (1954) Retail Trading in Britain 1850-1950 (Cambridge: Cambridge University Press).

Jobson's Year Book of Public Companies of Australia and New Zealand, various.

Jones, E. (1999) Coles Myer and grocery retailing in Australia in the twentieth-century Australia, Coles Myer Submission 168, Part 2, Report by the Joint Select Committee on the Retailing Sector. 
Kelly, G. J. (1994) Unregulated segment reporting: Australian evidence. British Accounting Review, 26: 217-34.

Kuwahara, H. (1997) Concentration and productivity in the retail trade in Japan. The International Review of Retail, Distribution and Consumer Research, 7, 2, 1997, 109-24.

Lane, P. J. and Lubatkin, M. (1998) Relative absorptive capacity and interorganizational learning. Strategic Management Journal, 19, 461-477.

McKinnon, J. L. and Dalimuntle, L. (1993) Voluntary disclosure of segment information by Australian diversified companies. Accounting and Finance, May: 33-50.

Merrilees B. and Miller, D. (2001) Innovation and strategy in the Australian supermarket industry. Journal of Food Products Marketing, 7: 3-18.

Murray, J. (1999) The Woolworths Way: A Great Australian Success Story 1924-1999. (Woolworths Limited).

Nayga, R. M. Jr. and Riethmuller, P. (1995). Recent developments in food retailing in the United States and Australia.

Review of Marketing and Agricultural Economics. 63, 1, 40-50.

Newbert, S. L. (2007) Empirical research on the resources-based view of the firm: An assessment and suggestions for future research. Strategic Management Journal, 28: 121-46.

Nordås, H. K., Grosso, M. G. and Pinali, E. (2008) Market structure in the distribution sector and merchandise trade. OECD Trade Policy Papers No. 68, http://dx.doi.org/10.1787/244328264654.

Pertzel, B. (2005) Stuart Stoneman: A Life in the Grocery Trade (Melbourne: Australian Scholarly Publishing).

Porter, M. E. (1980), Competitive Strategy: Techniques for Analyzing Industries and Competitors, New York: The Free Press.

Prahalad, C. K. and Hamel, G. (1990) The core competence of the corporation. Harvard Business Review, 68, 3:79-91.

Pratt, B. (2006) My Safeway Story: Making It Happen (Melbourne: Brolga Publishing).

Priem, R. L. and Butler, J. E. (2001). Is the resource-based "view" a useful perspective for strategic management research? Academy of Management Review, 26: 22-40.

Qian, H., and Acs, Z. J. (2013) An absorptive capacity theory of knowledge spillover entrepreneurship. Small Business Economics, 40, 2: 185-197.

Reardon, T., Timmer, C. P., Barrett and Berdegué, J. (2003) The rise of supermarkets in Africa, Asia and Latin America, American Journal of Agricultural Economics, 85, 5: 1140-1146.

Retail World (1993) Grocery Industry Marketing Guide - 1993. (Rozelle NSW: Retail World). 
Round, D. K. (1974) The industrial organization vacuum in Australia, Economic Record, 50, 2: 169-99.

Rouse, M. J. and Daellenbach, U. S. (1999) Rethinking research methods for resource-based perspectives: isolating sources of sustainable competitive advantages. Strategic Management Journal, 20: 487-94.

Rumelt, R. P. (1986), Strategy, Structure and Economic Performance (Boston, MA: Harvard Business School Press).

Safarin, A. E. (1985) FIRA and FIRB: Canadian and Australian Policies on Foreign Direct Investment, Ontario Economic Council, Discussion Paper Series.

Sammartino, A. (2007) Retail. In H. Dick and D. Merrett, eds., The Internationalisation Strategies of Small-Country Firms: The Australian Experience of Globalisation (Cheltenham: Edward Elgar), pp. 175-94.

Schedvin, C. B. (1992), In Reserve: Central Banking in Australia, 1945-75 (Sydney: Allen \& Unwin).

Seth, A. and Randall, G. (1999) The Grocers: The Rise and Rise of the Supermarket Chains (London: Kogan Page).

Stacey, N. A. H. and Wilson, A. (1958) The Changing Pattern of Distribution (Oxford: Pergamon Press).

Stannage, C. T. (1979), Sir Thomas Wardle, the grocer. In Hunt, I. ed., Westralian Portraits (Nedlands: University of Western Australia Press) pp. 286-95.

State Library of Victoria, Coles Myer archives MS13468/1.ARCHS001.

Sundstrom, W. A. (1988) Internal labor markets before World War 1: on-the-job training and employee promotion, Explorations in Economic History, 25,4: 424-45.

Sutton, J. (1991) Sunk Costs and Market Structure: Price Competition, Advertising and the Evolution of Concentration (Cambridge, MA: MIT Press).

Sydney Morning Herald, 'No frills' built grocery giants a fortune, 22 July 1978.

Teece, D. J., Pisano, G. and Shuen, A. (1997) Dynamic capabilities and strategic management. Strategic Management Journal, 18: 509-33.

Traill, W. B. (2006) The rapid rise of the supermarkets? Development Policy Review, 24, 2: 163-174.

Treadgold, A. (1996) Food retailing in Australia - three retailers, three strategies. International Journal of Retail \& Distribution Management, 24: 6-16.

Williamson, O. E. and Bhargava, N. (1972) Assessing and classifying the internal structure and control apparatus of the modern corporation. In Cowling, K., ed., Market Structure and Corporate Behaviour: Theory and Empirical Analysis of the Firm (London: Gray-Mills Publishing Ltd), pp. 126-48.

Woolworths Limited, Annual Report. Various.

Wrigley, N. (1992) Antitrust regulation and the restructuring of grocery retailing in Britain and the USA. Environment and Planning A, 24: 727-49.

This article is protected by copyright. All rights reserved. 
Zimmerman, M. M. (1955), The Supermarket: A Revolution in Distribution (New York: McGraw-Hill Book Company).

This article is protected by copyright. All rights reserved. 


\section{University Library}

\section{- M M N E R VA A gateway to Melbourne's research publications}

Minerva Access is the Institutional Repository of The University of Melbourne

Author/s:

Merrett, DT

Title:

The Making of Australia's Supermarket Duopoly, 1958-2000

Date:

2020-11-01

Citation:

Merrett, D. T. (2020). The Making of Australia's Supermarket Duopoly, 1958-2000. Australian Economic History Review: an Asia-Pacific journal of economic, business and social history, 60 (3), pp.301-321. https://doi.org/10.1111/aehr.12172.

Persistent Link:

http://hdl.handle.net/11343/286848 